\title{
Crystal structure, thermal behavior and vibrational studies of tetraethylammonium dihydrogenarsenate bis-arsenic acid $\left[\left(\mathrm{C}_{2} \mathrm{H}_{5}\right)_{4} \mathrm{~N}\right] \cdot\left[\mathrm{H}_{2} \mathrm{AsO}_{4}\right] \cdot\left[\mathrm{H}_{3} \mathrm{AsO}_{4}\right]_{2}$
}

\author{
Ikram Dhouib a,*, Philippe Guionneau b, Tahar Mhiri a and Zakaria Elaoud a \\ a Laboratoire de Physico-Chimie de l'Etat Solide, Département de Chimie, Faculté des Sciences de Sfax, Université de Sfax, Sfax 3000, Tunisia \\ b CNRS, Université de Bordeaux, ICMCB, 87 avenue du Dr A. Schweitzer, Pessac, F-33608, France \\ ${ }^{*}$ Corresponding author at: Laboratoire de Physico-Chimie de l'Etat Solide, Département de Chimie, Faculté des Sciences de Sfax, Université de Sfax, Sfax 3000 \\ Tunisia. \\ Tel.: +2.169.7019206. Fax: +2.167.4274437. E-mail address: ikramdhouib82@yahoo.fr (I. Dhouib).
}

\section{ARTICLE INFORMATION}

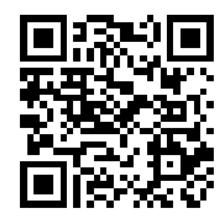

DOI: 10.5155 /eurjchem.5.3.388-393.1038

Received: 26 February 2014

Received in revised form: 13 March 2014

Accepted: 13 March 2014

Online: 30 September 2014

\section{KEYWORDS}

\section{Arsenic acid}

Crystal structure

Organic compounds

Raman spectroscopy

Infrared spectroscopy

Differential scanning calorimetry

\section{Introduction}

The combination of organic molecules and inorganic materials was the starting point for the development of new hybrid compounds, with desired physical and chemical properties [1,2]. These compounds have attracted great attention because of their unique opportunity to combine the remarkable features of organic compounds with those of inorganic materials. Their applications have been explored and reported in various fields, such as electronic $[3,4]$, optical $[5,6]$ magnetic $[7,8]$ and ferroelectric $[9,10]$.

In organic-cation monophosphate/monoarsenate, the phosphate/arsenate anions are interconnected by strong hydrogen bonds so as to build infinite networks with various geometries: ribbons [11], chains [12,13], two-dimensional network [14,15], and three-dimensional network [16].

On the other hand, there is still growing interest in the study of crystal containing tetra-alkylammonium cations of the general formula $\left(\mathrm{C}_{n} \mathrm{H}_{2 \mathrm{n}+1}\right)_{4} \mathrm{~N}^{+}$such as $\left(\mathrm{CH}_{3}\right)_{4} \mathrm{~N}^{+},\left(\mathrm{C}_{2} \mathrm{H}_{5}\right)_{4} \mathrm{~N}^{+}$and $\left(\mathrm{C}_{3} \mathrm{H}_{7}\right)_{4} \mathrm{~N}^{+}$. The specific geometry of these cations can generate supramolecular networks in one, two or three dimensions. Recently, numerous tetra-ethylammonium derivatives structural and vibrational studies have been published [17-18].
However, in conjunction with some resent works on these hybrids compounds, the crystal structure and vibrational studies of many organic-inorganic crystals have been investigated in our laboratory [19-21]. The present work deals with the growth, single crystal X-ray diffraction (XRD) study, thermal analysis and the detailed vibrational spectral analysis of a new organic-inorganic: tetraetylammonium dihydrogen monoarsenate bis-arsenic acid (TEAs).

\section{Experimental}

\subsection{Synthesis}

The crystal of the title compound, TEAs, is prepared by slow evaporation at room temperature of an aqueous solution of arsenic acid $\mathrm{H}_{3} \mathrm{AsO}_{4}$, and tetraethylammonium hydroxide $\left[\mathrm{CH}_{3} \mathrm{CH}_{2}\right]_{4} \mathrm{NOH}$ in the stoichiometric ratio (3:1) and mixed well using a magnetic stirrer to ensure homogenous concentration in the entire volume of the solution. The solutions which allowed evaporating at room temperature a few days until colorless parallel piped shaped monocrystals of TEAs were formed. The reaction scheme involved in the formation of complex compound is given in (1). 


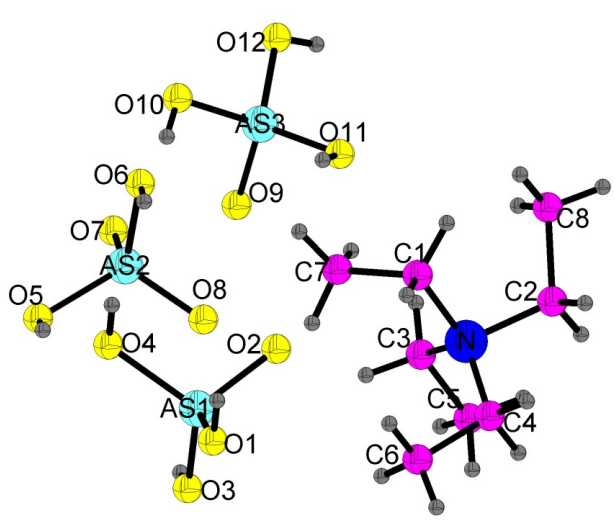

Figure 1. The asymmetric unit of $\left[\left(\mathrm{CH}_{3} \mathrm{CH}_{2}\right)_{4} \mathrm{~N}\right]\left(\mathrm{H}_{2} \mathrm{AsO}_{4}\right)\left(\mathrm{H}_{3} \mathrm{AsO}_{4}\right)_{2}$.

$\left[\mathrm{CH}_{3} \mathrm{CH}_{2}\right]_{4} \mathrm{NOH}+3 \mathrm{H}_{3} \mathrm{AsO}_{4} \rightarrow\left[\left(\mathrm{CH}_{3} \mathrm{CH}_{2}\right)_{4} \mathrm{~N}\right] \cdot\left[\mathrm{H}_{2} \mathrm{AsO}_{4}\right] \cdot\left[\mathrm{H}_{3} \mathrm{AsO}_{4}\right]_{2}+\mathrm{H}_{2} \mathrm{O}$

\subsection{X-ray single crystal structure determination}

The structure of TEAs was determined by the X-ray single crystal diffraction method. In each case, a suitable crystal was selected under a polarizing microscope and mounted on a thin glass fiber. The unit cell dimensions of salt was measured and refined using indexation of diffraction markings collected with a Kappa CAD4 automated four-circle diffractometer (graphitemonochromated MoK $\alpha$ radiation, $\lambda=0.71073 \AA$ ). Peak search, centering, indexing and least squares refinement routines led to a monoclinic unit cell for the compound. The final unit cell constants were determined by a least-squares fit of 5066 reflections. The crystal structure was solved by direct methods using SHELXS-97 [22] and difference Fourier synthesis. All the hydrogen positions were geometrically and affined located.

\subsection{Spectroscopic measurements}

The Fourier transform infrared (FT-IR) spectrum of TEAs was recorded in the range 4000-400 $\mathrm{cm}^{-1}$, with samples in $\mathrm{KBr}$ pellets using Perkin-Elmer FT-IR spectrometer. The resolution of the spectrum is $\pm 2 \mathrm{~cm}^{-1}$. The Fourier transform Raman (FTRaman) spectrum of the same compound was recorded using Horiba Jobin Yvon LabRAM HR 800 Dual spectrophotometer. The incident laser excitation is $632 \mathrm{~nm}$. The scattered light was collected at the angle of $180^{\circ}$ in the region $3600-50 \mathrm{~cm}^{-1}$ and the resolution was set up to $2 \mathrm{~cm}^{-1}$.

\section{Results and discussion}

\subsection{Structural analysis of TEAs}

The crystals of the title compound belong to the centrosymmetric Cc space group of the monoclinic system, with $Z=4$. The lattice parameters are listed in Table 1. The bond lengths and angles are collected in Table 2.

The asymmetric unit is composed of one $\left[\mathrm{H}_{2} \mathrm{AsO}_{4}\right]^{-}$anion, two neutral arsenic acid $\left[\mathrm{H}_{3} \mathrm{AsO}_{4}\right]$ and one $\left[\left(\mathrm{CH}_{3} \mathrm{CH}_{2}\right)_{4} \mathrm{~N}\right]^{+}$cation (Figure 1). The structure consists of infinite parallel twodimensional planes built of mutually $\left[\mathrm{H}_{2} \mathrm{AsO}_{4}\right]-\left[\mathrm{H}_{3} \mathrm{AsO}_{4}\right]$ tetrahedra and $\left(\mathrm{CH}_{3} \mathrm{CH}_{2}\right)_{4} \mathrm{~N}^{+}$cations, the projection along the $b$ axis of the atomic arrangement is depicted in Figure 2.

The coordination of arsenic atoms is tetrahedral with As-0 distances and 0 -As-O angles in the ranges (1.622(13); 1.796(7) $\AA ̊)$; $\quad(1.556(14) ; \quad 1.739(10) \AA) ; \quad(1.634(10) ; \quad 1.718(8) \AA)$; (107.7(5); 113.5(6) $)^{\circ}$; $\left(103.1(6) ; 114.8(6)^{\circ}\right)$ and (103.0(5); $\left.115.8(5)^{\circ}\right)$ for $\left[\mathrm{H}_{3} \mathrm{As}(1) \mathrm{O}_{4}\right] ;\left[\mathrm{H}_{2} \mathrm{As}(2) \mathrm{O}_{4}\right]^{-}$and $\left[\mathrm{H}_{3} \mathrm{As}(3) \mathrm{O}_{4}\right]$, respectively. The calculated average values of the distortion indices [23] corresponding to the different distances and angles in $\left[\mathrm{AsO}_{4}\right]$ tetrahedral $\mathrm{DI}(\mathrm{As}(1) 0)=0.0290, \operatorname{DI}(\mathrm{As}(2) 0)=$ 0.0384, $\operatorname{DI}(\operatorname{As}(3) 0)=0.0162, \operatorname{DI}(\operatorname{OAs}(1) 0)=0.0197$, $\mathrm{DI}(\mathrm{OAs}(2) 0)=0.0245, \mathrm{DI}(\mathrm{OAs}(3) 0)=0.0326, \mathrm{DI}(00)=0.0167$, $\mathrm{DI}(00)=0.0123$ and $\mathrm{DI}(00)=0.0155$ show a high distortion of the (OO) distances of $\left[\mathrm{H}_{3} \mathrm{As}(1) \mathrm{O}_{4}\right] ; \quad\left[\mathrm{H}_{2} \mathrm{As}(2) \mathrm{O}_{4}\right]^{2-}$ and $\left[\mathrm{H}_{3} \mathrm{As}(3) \mathrm{O}_{4}\right]$, respectively.

Table 1. Crystal data and summary of intensity data collection and structure refinement of TEAs.

\begin{tabular}{ll}
\hline Parameter & TEAs \\
\hline Formula & $\mathrm{C}_{8} \mathrm{H}_{28} \mathrm{NAs}_{3} \mathrm{O}_{12}$ \\
Temperature $(\mathrm{K})$ & $293.0(2)$ \\
Wavelength $\mathrm{MoK} \alpha\left(\mathrm{A}^{\circ}\right)$ & 0.71073 \\
Crystal system & Monoclinic \\
Space group & $C c$ \\
Unit cell dimensions & \\
$a(\AA)$ & $20.105(5)$ \\
$b(\AA)$ & $7.842(2)$ \\
$c(\AA)$ & $15.292(2)$ \\
$\beta\left({ }^{\circ}\right)$ & $115.00(2)$ \\
$Z$ & 4 \\
Calculated density, $\left(\mathrm{g} / \mathrm{cm}^{3}\right)$ & 1.53 \\
$F(000)$ & 999.8 \\
Crystal size $(\mathrm{mm})$ & $0.40 \times 0.20 \times 0.10$ \\
$\theta$ range for data collection $\left({ }^{\circ}\right)$ & $2.8-27.1$ \\
Index ranges & $-25 \leq h \leq 25$ \\
& $-9 \leq k \leq 1$ \\
$R_{\text {int }}$ & $-19 \leq l \leq 19$ \\
$\mathrm{R}_{(\text {sigma) }}$ & 0.0290 \\
$R=\sum\left\|\mathrm{F}_{\mathrm{o}}|-| \mathrm{F}_{\mathrm{c}}\right\| / \sum\left\|\mathrm{F}_{\mathrm{o}}\right\|$ & 0.0395 \\
$R_{w}$ & 0.071 \\
$T$ min & 0.2200 \\
$T$ max & 0.2604 \\
\hline
\end{tabular}

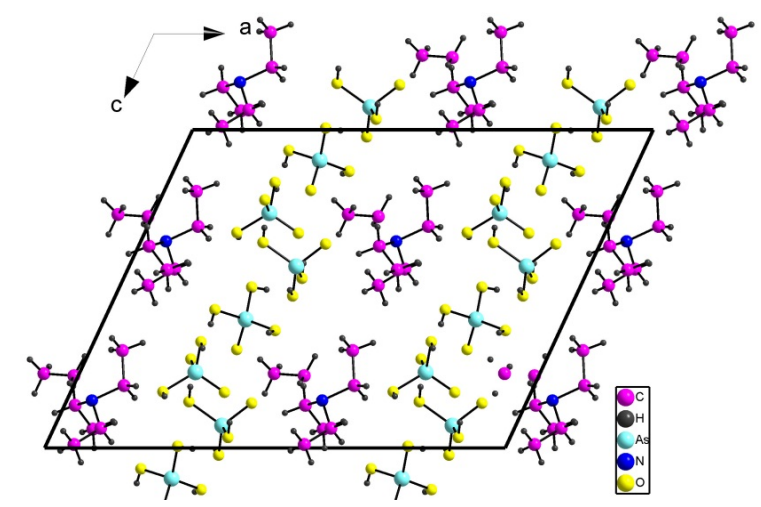

Figure 2. Projection along the $b$ axis of the atomic arrangement of $\left[\left(\mathrm{CH}_{3} \mathrm{CH}_{2}\right)_{4} \mathrm{~N}\right] \cdot\left[\mathrm{H}_{2} \mathrm{AsO}_{4}\right] \cdot\left[\mathrm{H}_{3} \mathrm{AsO}_{4}\right]_{2}$.

The structure is based on sheets of $\mathrm{H}_{2} \mathrm{AsO}_{4}{ }^{-}$and $\mathrm{H}_{3} \mathrm{AsO}_{4}$ tetrahedra bonded together by strong intra-layer $\mathrm{O}-\mathrm{H} \cdots \mathrm{O}$ hydrogen bonds, giving to trimmers built up by $\left[\left(\mathrm{H}_{3} \mathrm{AsO}_{4}\right)\right.$ $\left.\left(\mathrm{H}_{2} \mathrm{AsO}_{4}\right)\right]^{-}$clusters, $(\mathrm{dO}-\mathrm{O}<2.73 \AA)[24,25]$ as seen in Figure 3 . The mid-planes of these arsenic groups, are located at $x=0.25$ and $x=0.75$.

These hydrogen bonds contribute to the cohesion of the structure. The various hydrogen bond parameters are summarized in Table 3.

The organic cation are located at $x=0.0$ and $x=0.5$. The lengths of the $\mathrm{N}-\mathrm{C}$ bonds are in the range between 1.462(17) to $1.600(2) \AA$. The C-N-C angles range from 101.6(10) to $115.9(12)^{\circ}$. The C-C bonds lengths are in the region between $1.477(13)$ to $1.611(14) \AA$. They are in good agreement with those found in related compound [19,21].

\subsection{Vibrational analysis}

The FT-IR and FT-Raman spectra of the title crystals were measured for the powder sample at room temperature. 
Table 2. Principal interatomic distances $(\AA)$ and angles $\left({ }^{\circ}\right)$ in TEAs.

\begin{tabular}{|c|c|c|c|}
\hline Tetrahedron around As & Distances ( $)$ & {$\left[\mathrm{CH}_{3} \mathrm{CH}_{2}\right]_{4} \mathrm{~N}^{+}$cations } & Angles $\left({ }^{\circ}\right)$ \\
\hline $\operatorname{As}(1)-0(1)$ & $1.671(12)$ & $\mathrm{N}-\mathrm{C}(1)$ & $1.60(2)$ \\
\hline $\mathrm{As}(1)-\mathrm{O}(2)$ & $1.622(13)$ & $\mathrm{N}-\mathrm{C}(2)$ & $1.571(14)$ \\
\hline $\operatorname{As}(1)-0(3)$ & $1.663(14)$ & $\mathrm{N}-\mathrm{C}(3)$ & $1.470(14)$ \\
\hline $\operatorname{As}(1)-0(4)$ & $1.796(7)$ & $\mathrm{N}-\mathrm{C}(4)$ & $1.462(17)$ \\
\hline $\mathrm{O}(1)-\mathrm{H}(11)$ & 0.8200 & $C(1)-C(7)$ & $1.580(15)$ \\
\hline $\mathrm{O}(4)-\mathrm{H}(14)$ & 0.8200 & $\mathrm{C}(2)-\mathrm{C}(8)$ & $1.611(14)$ \\
\hline $\mathrm{O}(3)-\mathrm{H}(13)$ & 0.8200 & $C(3)-C(5$ & $1.556(13)$ \\
\hline $\mathrm{As}(2)-\mathrm{O}(5)$ & $1.731(9)$ & $C(4)-C(6)$ & $1.4777(3)$ \\
\hline $\operatorname{As}(2)-0(6)$ & $1.739(10)$ & $\mathrm{C}(1)-\mathrm{N}-\mathrm{C}(4)$ & $114.2(12)$ \\
\hline $\operatorname{As}(2)-0(7)$ & $1.657(9)$ & $\mathrm{C}(1)-\mathrm{N}-\mathrm{C}(2)$ & $104.9(11)$ \\
\hline $\mathrm{As}(2)-0(8$ & $1.556(14)$ & $\mathrm{C}(4)-\mathrm{N}-\mathrm{C}(2)$ & $101.6(10)$ \\
\hline $\mathrm{O}(5)-\mathrm{H}(22)$ & 0.8200 & $\mathrm{C}(1)-\mathrm{N}-\mathrm{C}(3)$ & $108.8(12)$ \\
\hline $\mathrm{O}(6)-\mathrm{H}(23)$ & 0.8200 & $\mathrm{C}(4)-\mathrm{N}-\mathrm{C}(3)$ & $115.9(12)$ \\
\hline $\operatorname{As}(3)-0(9)$ & $1.634(10)$ & $\mathrm{C}(2)-\mathrm{N}-\mathrm{C}(3)$ & $110.7(12)$ \\
\hline $\operatorname{As}(3)-\mathrm{O}(10)$ & $1.718(8)$ & $C(8)-C(2)-N$ & $114.1(12)$ \\
\hline $\operatorname{As}(3)-0(11)$ & $1.704(7)$ & $C(6)-C(4)-N$ & $112.7(6)$ \\
\hline $\operatorname{As}(3)-0(12)$ & $1.698(11)$ & $C(5)-C(3)-N$ & $108.7(10)$ \\
\hline $\mathrm{O}(10)-\mathrm{H}(33)$ & 0.8200 & $\mathrm{C}(1)-\mathrm{C}(7)-\mathrm{N}$ & $98.1(9)$ \\
\hline $\mathrm{O}(11)-\mathrm{H}(34)$ & 0.8200 & & \\
\hline $\mathrm{O}(12)-\mathrm{H}(31)$ & 0.8200 & & \\
\hline$O(2)-\operatorname{As}(1)-O(4)$ & $107.7(5)$ & & \\
\hline$O(2)-\operatorname{As}(1)-O(1)$ & $107.7(5)$ & & \\
\hline$O(4)-\operatorname{As}(1)-O(1)$ & $113.5(6)$ & & \\
\hline $\mathrm{O}(4)-\operatorname{As}(1)-\mathrm{O}(3)$ & $108.6(5)$ & & \\
\hline $\mathrm{O}(1)-\operatorname{As}(1)-\mathrm{O}(3)$ & $109.4(6)$ & & \\
\hline $\mathrm{O}(2)-\mathrm{As}(1)-\mathrm{O}(3)$ & $113.0(6)$ & & \\
\hline $0(6)-\operatorname{As}(2)-0(5)$ & $107.6(6)$ & & \\
\hline$O(6)-\operatorname{As}(2)-O(7)$ & $109.7(5)$ & & \\
\hline $0(5)-\operatorname{As}(2)-0(7)$ & $110.6(5)$ & & \\
\hline $0(6)-\operatorname{As}(2)-0(8)$ & $103.1(6)$ & & \\
\hline $0(5)-\operatorname{As}(2)-0(8)$ & $110.5(6)$ & & \\
\hline $\mathrm{O}(7)-\mathrm{As}(2)-\mathrm{O}(8)$ & $114.8(6)$ & & \\
\hline$O(11)-\operatorname{As}(3)-O(10)$ & $108.6(4)$ & & \\
\hline$O(11)-A s(3)-O(9)$ & $106.2(5)$ & & \\
\hline$O(10)-A s(3)-O(9)$ & $109.2(5)$ & & \\
\hline$O(11)-A s(3)-O(12)$ & $115.8(5)$ & & \\
\hline$O(10)-A s(3)-O(12)$ & $103.0(5)$ & & \\
\hline$O(9)-A s(3)-O(12)$ & $113.8(3)$ & & \\
\hline
\end{tabular}

Table 3. Bond lengths $(\AA)$ and bond angles $\left(^{\circ}\right)$ in the hydrogen bonding scheme of $\left[\left(\mathrm{CH}_{3} \mathrm{CH}_{2}\right)_{4} \mathrm{~N}\right] .\left[\mathrm{H}_{2} \mathrm{AsO}_{4}\right] \cdot\left[\mathrm{H}_{3} \mathrm{AsO}_{4}\right]_{2}$.

\begin{tabular}{|c|c|c|c|c|}
\hline 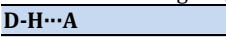 & d(D-H) $(\AA)$ & $d(H \cdots A)(\AA)$ & $d(D \cdots A)(\AA)$ & $\angle \mathrm{D}-\mathrm{H} \cdots \mathrm{A}\left({ }^{\circ}\right)$ \\
\hline $\mathrm{O}(3)-\mathrm{H}(13) \cdots \mathrm{O}(12)^{\mathrm{i}}$ & 0.82 & 2.04 & $2.669(15)$ & 132.7 \\
\hline $\mathrm{O}(4)-\mathrm{H}(14) \cdots \mathrm{O}(7)$ & 0.82 & 1.80 & $2.614(13)$ & 169.4 \\
\hline $\mathrm{O}(5)-\mathrm{H}(22) \cdots \mathrm{O}(12)^{\text {iv }}$ & 0.82 & 2.25 & $2.560(13)$ & 102.5 \\
\hline $\mathrm{O}(6)-\mathrm{H}(23) \cdots \mathrm{O}(9) \mathrm{ii}$ & 0.82 & 1.86 & $2.453(16)$ & 128.7 \\
\hline $\mathrm{O}(10)-\mathrm{H}(33) \cdots \mathrm{O}(7)$ & 0.82 & 1.82 & $2.581(13)$ & 154.3 \\
\hline $\mathrm{O}(12)-\mathrm{H}(31) \cdots \mathrm{O}(3)^{\mathrm{iii}}$ & 0.82 & 1.87 & $2.669(15)$ & 165.3 \\
\hline
\end{tabular}

Symmetry codes: (i) $x,-y+1, z+1 / 2$; (ii) $x, y-1, z$; (iii) $x,-y+1, z-1 / 2$; (iv) $x,-y, z+1 / 2$.

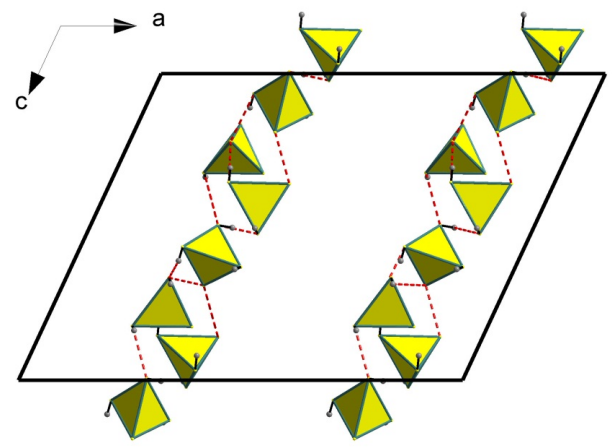

Figure 3. Projection along the $b$ axis of the inorganic arrangement of TEAs.

The bands observed in the measured region arise from the vibrations of hydrogen bonds, vibrations of the tetraethyl ammonium cation, arsenic, groups and lattice vibrations. Vibrational spectra are shown in Figure 4-5.

The vibrational analysis of an isolated arsenate, phosphate anion $\mathrm{AsO}_{4}{ }^{3-}$, with $T_{\mathrm{d}}$ point group symmetry leads to four Raman active normal modes: $v_{1}\left(A_{1}\right), v_{2}(E), v_{3}\left(F_{2}\right)$ and $v_{3}\left(F_{2}\right)$ with average wavenumbers $837,349,887$ and $463 \mathrm{~cm}^{-1}$, respectively [26]. $v_{1}$ and $v_{3}$ involve the symmetric and the antisymmetric stretching mode of the As-O bonds, whereas $v_{2}$ involve mainly $\mathrm{O}$-As-0, symmetric and anti-symmetric bending modes. The IR and Raman spectra of TEAs, that we obtained consist of a number of distinct and well separated groups of bands, and can be divided into three frequency regions: 15-250 $\mathrm{cm}^{-1}$, lattice mode; $250-1200 \mathrm{~cm}^{-1}$, $\mathrm{AsO}_{4}{ }^{3-}$, internal modes and $1200-3700 \mathrm{~cm}^{-1}$, high-frequency hydrogen modes [27-29]. In 
TEAs crystal, the symmetry of $\mathrm{AsO}_{4}{ }^{3-}$, ions is reduced from $T_{\mathrm{d}}$ to $\mathrm{C}_{1}$. In fact, our structural study on TEAs shows that the As-0, distances and the $0-A s-0$, angles are distorted with respect to the hypothetical $T_{\mathrm{d}}$ symmetry. This symmetry change partially removes the degeneracy of the vibrational wave functions, which would have characterized free $\mathrm{AsO}_{4}{ }^{3-}$. In the 1000-300 $\mathrm{cm}^{-1}$ region, the $\mathrm{AsO}_{4}^{3-}$ stretching and bending vibrations expected to appear, as well as the modes associated to internal modes of the organic cations. However, in the light of our present calculations as primary source of assignment and by comparison with similar organic arsenic compound, we have been distinguishing between the bands originating from the vibrations of arsenate groups and the organic cations. The medium band at $907 \mathrm{~cm}^{-1}$ in Raman spectrum is assigned to the asymmetric stretching $v_{3}$ mode of the arsenate ion. In IR spectrum, this mode appears also as a single strong band at 920 $\mathrm{cm}^{-1}$. The band due to the symmetric stretching mode $v_{1}$ vibration is located in Raman spectrum at 829 and $671 \mathrm{~cm}^{-1}$ as a strong band. In IR spectrum this mode appears as a strong band at 822 and $677 \mathrm{~cm}^{-1}$. The bands due to the symmetric and asymmetric bending vibration $v_{2}$ and $v_{4}$ of the arsenate ion are identified in the $550-400 \mathrm{~cm}^{-1}$ and $400-300 \mathrm{~cm}^{-1}$ frequency region, respectively. The very strong band observed in Raman spectrum at $417 \mathrm{~cm}^{-1}$ can be easily assigned to $v_{4}$ mode, whereas the symmetric mode $v_{2}$ appears in Raman spectrum as weak band at $324 \mathrm{~cm}^{-1}$.

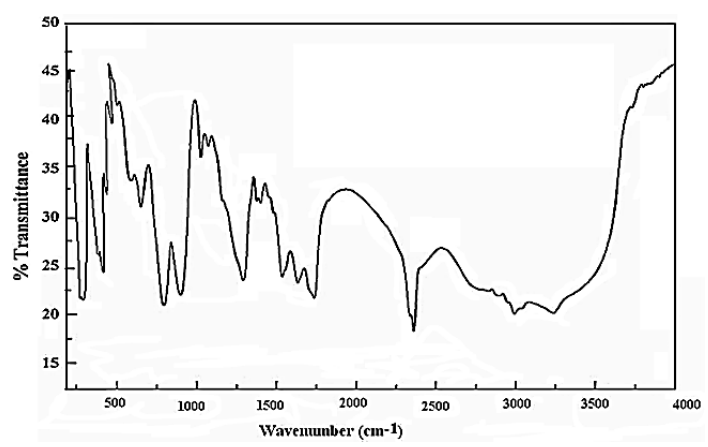

Figure 4. IR spectrum of $\left[\left(\mathrm{CH}_{3} \mathrm{CH}_{2}\right)_{4}\right] \mathrm{N}\left(\mathrm{H}_{2} \mathrm{AsO}_{4}\right)\left(\mathrm{H}_{3} \mathrm{AsO}_{4}\right)_{2}$.

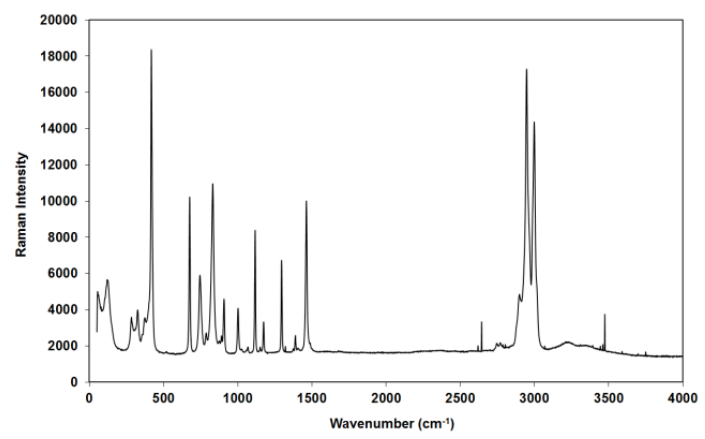

Figure 5. Raman spectrum of $\left[\left(\mathrm{CH}_{3} \mathrm{CH}_{2}\right)\right]_{4} \mathrm{~N}\left(\mathrm{H}_{2} \mathrm{AsO}_{4}\right)\left(\mathrm{H}_{3} \mathrm{AsO}_{4}\right)_{2}$.

Numerous functional and skeletal groups such as $\mathrm{CH}_{2}, \mathrm{CH}_{3}$, $\mathrm{C}-\mathrm{N}, \mathrm{C}-\mathrm{C}$ and $\mathrm{NC}_{4}$ are present in tetrapropylammonium cation. These groups are manifested in IR and Raman spectra in different range with different intensity.

It is well known that $\mathrm{CH}_{3}$ groups have $\mathrm{C}_{3 \mathrm{v}}$ symmetry in the free state with pyramidal structure of TEAs. Their normal modes of vibrations are $v_{1}\left(A_{1}\right), v_{2}\left(A_{1}\right), v_{3}(E)$ and $v_{4}(E)$. All these modes are both infrared and Raman active with the asymmetric stretching and bending modes being doubly degenerate. The asymmetric and symmetric $\mathrm{CH}_{3}$ stretching vibrations in aliphatic compound are usually observed in the region 2990-
$2850 \mathrm{~cm}^{-1}$ [30-31]. In the title compound the doubly degenerate asymmetric stretching and bending modes $v_{3}(E)$ and $v_{4}(E)$ are observed in the split form. The weak band at $2944 \mathrm{~cm}^{-1}$ and the shoulder one at $2948 \mathrm{~cm}^{-1}$ in IR spectrum are attributed to the asymmetric stretching vibration and the Raman counterparts are located as a very strong band at $2997 \mathrm{~cm}^{-1}$. The symmetric stretching mode of $\mathrm{CH}_{3}$ is assigned to the shoulder band at $2897 \mathrm{~cm}^{-1}$ in Raman spectrum. In IR spectrum this mode appears as a very weak intensity band at the $2848 \mathrm{~cm}^{-1}$. The asymmetric and symmetric bending mode of methyl group generally appears in the region $1550-1410$ and $1310-1400$ $\mathrm{cm}^{-1}$, [32-33]. In the present case, two FT-IR bands with slightly different intensity at 1447 and $1478 \mathrm{~cm}^{-1}$ are assigned to $\mathrm{CH}_{3}$ asymmetric bending mode. In Raman spectrum, their corresponding bands appear as a very shoulder band at 1452 $\mathrm{cm}^{-1}$ and as a very strong one at $1462 \mathrm{~cm}^{-1}$. The symmetric bending mode of the $\mathrm{CH}_{3}$ group is seen at $1392 \mathrm{~cm}^{-1}$ as a medium band in the IR spectrum and as a very strong band at $1385 \mathrm{~cm}^{-1}$ in Raman spectrum. The methyl rocking vibration is observed as a weak band at $997 \mathrm{~cm}^{-1}$ in IR spectrum and at $1001 \mathrm{~cm}^{-1}$ as a medium one in Raman spectrum.

The wavenumber of the $\mathrm{CH}_{2}$ vibrational modes depend on its immediate environment. The stretching modes of the $\mathrm{CH}_{2}$ group usually occur in the region $3100-2800 \mathrm{~cm}^{-1}$ [34-35]. In TEAs crystal, the $\mathrm{CH}_{2}$ asymmetric and symmetric stretching modes are not identified in IR spectrum. These bands are probably masked by the broad bands of $\mathrm{CH}_{3}$ stretching vibrations. The weak band located at $2874 \mathrm{~cm}^{-1}$ in Raman spectrum is assigned to the $\mathrm{CH}_{2}$ symmetric stretching mode. The deformation modes of this group lie in the same region as the deformation modes of $\mathrm{CH}_{3}$. Since the deformation modes of methyl group are intense, the deformation modes of $\mathrm{CH}_{2}$ are also not identified. However the wagging, twisting and the rocking modes of the $\mathrm{CH}_{2}$ group were observed and assigned.

The primitive unit cell of the title compound contains one tetraethylammonium $\left(\mathrm{NC}_{4}\right)^{+}$cation not coupled with the inorganic parts as revealed by the X-Ray diffraction. Then, it is convenient as a first approach to consider the $\mathrm{NC}_{4}$ core of the isolated cation with Td symmetry and therefore exhibits four normal modes. According to the literature, the vibrations related to $\mathrm{NC}_{4}$ group shown in tetraethylammonium cation of TEAs are described as: symmetric stretching mode $v_{1}(\mathrm{~A})$ to be found at $752 \mathrm{~cm}^{-1}$, [36-38] asymmetric stretching mode $v_{3}\left(F_{2}\right)$ located at $955 \mathrm{~cm}^{-1}$, asymmetric bending mode $v_{4}\left(F_{2}\right)$ observed at $455 \mathrm{~cm}^{-1}$ and the symmetric bending mode $v_{2}\left(F_{2}\right)$ at $372 \mathrm{~cm}^{-1}$ $[32,39]$. In our case the weak band appeared at $1001,1000 \mathrm{~cm}^{-1}$ is related to the $v_{3}$ mode. His counterpart appears in IR spectrum as shoulder band at $988 \mathrm{~cm}^{-1}$. The weak band observed in Raman spectrum at $744 \mathrm{~cm}^{-1}$ arises from the $v_{1}$ symmetric stretching mode. The bands assigned to the symmetric and asymmetric bending modes of $\mathrm{NC}_{4}$ core of the isolated cation are observed in Raman spectrum at $383 \mathrm{~cm}^{-1}$ respectively whereas the corresponding calculated values for these modes are located at $393 \mathrm{~cm}^{-1}$, respectively. It is interest to note that the vibrational mode of the $\mathrm{NC}_{4}$ group do not deviate much from their expected values, suggesting that the interaction of this group with the environment is not strong on the other hand, we note also that our assignment of $\mathrm{NC}_{4}$ agree well with the previous reported vibrational studies of the tetraethylammonium salts [40].

It is well known that hydrogen bonding brings a remarkable downward wavenumber shifts. The intermolecular hydrogen bonds give rise to broad bands, whereas bands arising from intramolecular hydrogen bonds are sharp and well resolved. Other information which can be obtained from the vibrational spectra concerns the strength and the type of 0 $\mathrm{H} \cdots \mathrm{O}$ hydrogen bonds, which remain practically the same in the strongly hydrogen bonded crystals such as $\mathrm{KH}_{2} \mathrm{PO}_{4}, \mathrm{NaH}_{2} \mathrm{PO}_{4}$, $\mathrm{CsHSO}_{4}$, and $\mathrm{CsH}_{2} \mathrm{PO}_{4}$ [41-44]. The corresponding $\mathrm{OH}$ stretching vibration gives rise to characteristic broad trio bands of $\mathrm{ABC}$ type, associated with strongly hydrogen-bonded systems. 
These bonds have been interpreted as $\mathrm{OH}$ stretching modes in Fermi resonance with combinations involving mainly $\mathrm{OH}$ bending vibrations or in terms of a strong coupling between fast $\mathrm{OH}$ and $0 \cdots \mathrm{O}$ stretching modes $[45,46]$. By knowing the bond length, the strength of the hydrogen bond can be determined as very strong (below $2.5 \AA$ ), strong (2.5-2.7 $\AA$ ), normal $(2.7-2.9 \AA$ ) and weak (above $2.9 \AA$ ). X-ray diffraction analysis of TEAs, reveal that the structure is based on sheets of $\mathrm{H}_{2} \mathrm{AsO}_{4}{ }^{-}, \mathrm{H}_{3} \mathrm{AsO}_{4}$ tetrahedra bonded together by strong intralayer $\mathrm{O}-\mathrm{H} \cdots \mathrm{O}$ hydrogen bonds, giving to trimmers. The inspection of the IR spectrum reveals a broad and strong band at $3660 \mathrm{~cm}^{-1}$. We have assigned this band to the stretching mode $v(\mathrm{OH})$ which is not implied in hydrogen bonding. Two broad and weak bands in IR spectrum located at 3526 and $3440 \mathrm{~cm}^{-1}$ are assigned to $v(\mathrm{O}-\mathrm{H} \cdots \mathrm{O})$ modes. In Raman spectrum, a broad and weak band at $3244 \mathrm{~cm}^{-1}$ is also assigned to $v(\mathrm{O}-\mathrm{H} \cdots \mathrm{O})$ stretching modes. The in-plane $\mathrm{OH}$ bending mode $\delta \mathrm{OH}$ gives rise to a medium band in infrared spectrum with a counterpart in Raman spectrum at $1244 \mathrm{~cm}^{-1}$. The out-of-plane bending $\gamma \mathrm{OH}$ mode appears in the region $900-700 \mathrm{~cm}^{-1}$.

\subsection{Calorimetric study}

DSC-TG of TEAs was done in air at the rate of $5{ }^{\circ} \mathrm{C} / \mathrm{min}$. One more characteristic feature of the room temperature TEAs is its high hygroscopicity (Figure 6-7) which, illustrates the calorimetric (DSC) and thermogravimetric (TGA) results. This compound is stable until $345 \mathrm{~K}$, above this temperature; a loss of weight appears at $369 \mathrm{~K}$ of TEAs. It is due to the departure of adsorbed water. The two endothermic peak observed at $\mathrm{T}=$ $388 \mathrm{~K}$ is attributed to the melting of TEAs.

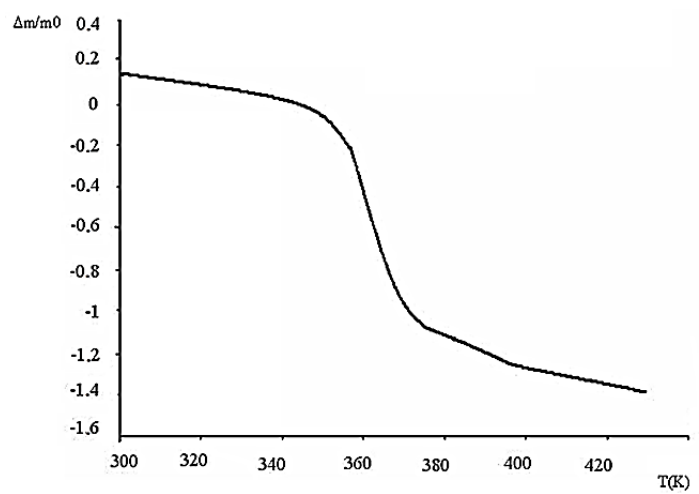

Figure 6. The TG curve of $\left[\left(\mathrm{CH}_{3} \mathrm{CH}_{2}\right)_{4}\right] \mathrm{N}\left(\mathrm{H}_{2} \mathrm{AsO}_{4}\right)\left(\mathrm{H}_{3} \mathrm{AsO}_{4}\right)_{2}$.

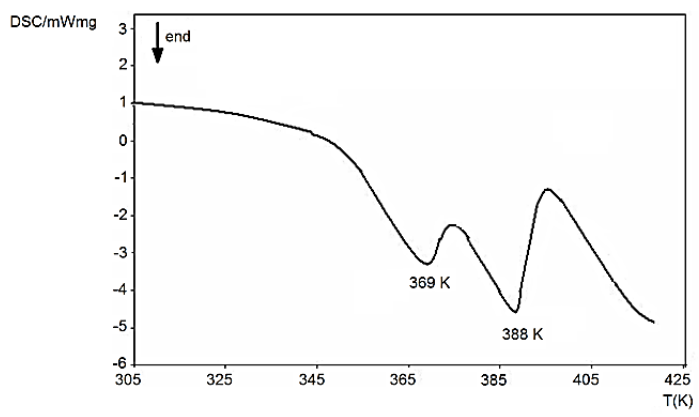

Figure 7. The DSC curve of $\left[\left(\mathrm{CH}_{3} \mathrm{CH}_{2}\right)_{4}\right] \mathrm{N}\left(\mathrm{H}_{2} \mathrm{AsO}_{4}\right)\left(\mathrm{H}_{3} \mathrm{AsO}_{4}\right)_{2}$.

\section{Conclusion}

The new hybrid material, $\left[\left(\mathrm{CH}_{3} \mathrm{CH}_{2}\right)_{4} \mathrm{~N}\right] \cdot\left[\mathrm{H}_{2} \mathrm{AsO}_{4}\right] \cdot\left[\mathrm{H}_{3} \mathrm{AsO}_{4}\right]_{2}$, has been synthesized and investigated by thermal analysis, single crystal X-ray diffraction and vibrational spectroscopy.
The structure consist of strong two dimensional character based on sheets of $\mathrm{H}_{2} \mathrm{AsO}_{4}-$ and $\mathrm{H}_{3} \mathrm{AsO}_{4}$ tetrahedra fused together by strong intra-layer $\mathrm{O}-\mathrm{H} \cdots \mathrm{O}$ hydrogen bonds, giving to trimmers and infinite chains. Vibrational study recorded is of great interest as it verifies the dependence of groups constituting our material. The hydrogen bonds confirmed by IR and X-Ray diffraction explain the stability of our compound. DSC anomalies definitively indicate on adsorbed water and on melting.

\section{Acknowledgement}

Grateful thanks are expressed in Dr. Philippe Guionneau (Service Rayons X /ICMCB CNRS Bordeaux) for the assistance in single crystal X-ray diffraction data collection.

\section{Supplementary material}

CCDC-927292 contains the supplementary crystallographic data for this paper. These data can be obtained free of charge via www.ccdc.cam.ac.uk/data_request/cif, or by e-mailing data request@ccdc.cam.ac.uk, or by contacting The Cambridge Crystallographic Data Centre, 12 Union Road, Cambridge CB2 1EZ, UK; fax: +44(0)1223-336033.

\section{References}

[1]. Laine, R.; Sanchez , C.; Brinker, C. J.; Gianellis (Eds.), E. Organic/Inorganic Hybrid Materials, Materials Research Society Series, Vol. 628, Pittsburgh, PA. 2000.

[2]. Sanchez, C.; Lebeau, B. Mater. Res. Soc. Bull. 2001, 26, 377-387.

[3]. Zdanowska-Fraczek, M.; Holderna-Natkaniec, K.; Fraczek, Z. J.; Jakubas, R. Solid State Ion. 2009, 180, 9-12.

[4]. Chaabane, I.; Hlel, F.; Guidara, K. J. Alloys Compd. 2008, 461, 495-500.

[5]. Sakai, K.; Takemura, M.; Kawabe, Y. J. Lumin. 2010, 130, 2505-2507.

[6]. Pradeesha, K.; Sharachandar, Y. G.; Singhb, M.; Vijaya, P. G. Mater Chem. Phys. 2010, 124, 44-47.

[7]. Vishwakarma, A.; Ghalsasi, P.; Navamoney, A.; Lan, Y.; Powell, A. Polyhedron 2011, 30, 1565-1570.

[8]. Aruta, C.; Licci, F.; Zappettini, A.; Bolzoni, F.; Rastelli, F.; Ferro, P.; Bezagni, T. Appl. Phys. A 2005, 81, 963-968.

[9]. Bujak, M.; Zaleski, J. Cryst. Eng. 2001, 4, 241-243.

[10]. Karoui, K.; Rhaiem, A. B.; Guidara, K. Physica B 2012, 407, 489-493.

[11]. Baouab, L.; Jouini, A. J. Solid State Chem. 1998, 141, 343-351.

[12]. Averbuch-Pouchot, M. T.; Durif, A. Acta Cryst. C 1987, 43, 1894-1896.

[13]. Averbuch-Pouchot, M. T.; Durif, A.; Guitel, J. C. Acta Cryst. C 1988, 44, 1968-1972.

[14]. Averbuch-Pouchot, M. T.; Durif, A.; Guitel, J. C. Acta Cryst. C 1988, 44, 99-102.

[15]. Bagieu-Beucher, M. Acta Cryst. C 1990, 46, 238-240.

[16]. Averbuch-Pouchot, M. T.; Durif, A.; Guitel, J. C. Acta Cryst. C 1989, 45, 421-423.

[17]. Baran, J.; Sledz, M.; Drozd, M.; Pietraszko, A.; Haznar, A.; Ratajczak, H. J. Mol. Struct. 2000, 526, 361-371.

[18]. Amirthaganesan, G.; Kandaswamy, M. A.; Dhandapani, M. Mater. Chem. Phys. 2008, 110, 328-331.

[19]. Dhouib, I.; Al-Juaid, S.; Mhiri, T.; Elaoud, Z. Cryst. Struct. Theory Appl. 2013, 2, 8-15.

[20]. Dhouib, I.; Elaoud, Z.; Mhiri, T.; Daoud, A. J. Chem. Crystallogr. 2012, $42,5,513-518$.

[21]. Dhouib, I.; Guionneau, P.; Pechev , S.; Mhiri, T.; Elaoud, Z. Eur. J. Chem. 2013, 4(2), 117-120.

[22]. Sheldrick, G. M.; SHELX-97, Program for the Solution of Crystal Structures and Crystal Determination, Univ. of Göttingen: Germany, 1997.

[23]. Baur, W. Acta Crystallgr. B 1974, 30, 1195-1215.

[24]. Brown, I. D. Acta Cryst. A 1976, 32, 24-31.

[25]. Blessing, R. H. Acta Cryst. B 1986, 42, 604-613.

[26]. Nailii, H.; Mhiri, T.; Jaud, J. J. Solid. State Chem. 2001, 161, 9-16.

[27]. Le Calve, N.; Romain, F.; Limage, M. H.; A. Novak, A. J. Mol. Struct 1989, 200, 131-137.

[28]. Hubert, J. I.; Jayakumar, V. S.; Aruldhas, G. J. Solid State Chem. 1995, 120, 343-347.

[29]. Romain, F.; Novak, A. J. Mol. Struct. 1991, 263, 69-74.

[30]. Rui-Zhou, Z.; Xiao-Hong, L. Xian-Zhou, Z. Chin. J. Struct. Chem. 2012 $31,1395-1408$.

[31]. Silverstein, R. M.; Webster, F. X. Spectrometric, Identification of Organic Compounds, Wiley, New York, 1973.

[32]. Gosniowska, M.; Ciunik, Z.; Bator, G.; Jakubas, R.; Baran, J. J. Mol. Struct 2000, 555, 243-255. 
[33]. Karbowiak, M.; Hanuza, J.; Janczak, J.; Drozdzynski, J. J. Alloys Compd. 1995, 225, 338-343.

[34]. Karabacak, M.; Cinar, Z.; Kurt, M.; Sudha, S.; Sundaraganesan, N. Spectrochim. Acta A 2012, 85, 179-189.

[35]. Colthup, N. B.; Daly, L. H.; Wiberley, S. E. Introduction to Infrared and Raman Spectroscopy, Academic Press, New York, 1990.

[36]. Heddrich, H. G.; Blom, C. E. J. Chem. Phys. 1989, 90, 4660-4663.

[37]. Heddrich, H. G.; Blom, C. E. J. Mol. Spectrosc. 1990, 140, 103-106.

[38]. Kirkwood, A. D.; Bier, K. D.; Thompson, J. K.; Haslett, T. L.; Hubber, A. S.; Moskovits, M. J. Phys. Chem. 1991, 95, 2644-2652.

[39]. Edsall, J. T. J. Chem. Phys. 1937, 5, 225-232.

[40]. Hajlaoui, S.; Chaabane, I.; Oueslati, A.; Guidara, K.; Bulou, A. Spectrochimi Acta A. 2014, 117, 225-233.

[41]. Marchon B.; Novak, A. J. Chem. Phys. 1985, 78, 2105-2110.

[42]. Ohno, N.; Lockwood, D. J. J. Chem. Phys. 1985, 83, 4374-3379.

[43]. Choi. B. K.; Kim, J. J. Jpn. J. Appl. Phys. 1985, 24, 912-914.

[44]. Baran, J. J. Mol. Struct. 1987, 162, 211-228.

[45]. Hadzi, D.; Bratos, S. The Hydrogen Bond, Vol. 2, North-Holland, Amsterdam, 1976, p. 565.

[46]. Hofacker, G. L.; Marechal, Y.; Ratner, M. A. The Hydrogen Bond, Vol. 1, North-Holland, Amsterdam, 1976, p. 295. 